\title{
Construction and validation of an educational booklet to provide care for snakebite victims
}

\author{
Maria Beatriz da Silva Cunha ${ }^{a}$ \\ Kairo Cardoso da Frota ${ }^{b}$ \\ Keila Maria de Azevedo Ponte ${ }^{b}$ \\ Tamires Alexandre Felix ${ }^{c}$
}

\section{How to cite this article:} Cunha MBS, Frota KC, Ponte KMA, Felix TA. Construction and validation of an educational booklet to provide care for snakebite victims. Rev Gaúcha Enferm. 2020;41:e20190467. doi: https://doi. org/10.1590/1983-1447.2020.20190467 a Universidade Estadual Vale do Acaraú (UVA). Sobral, Ceará, Brasil.

- Universidade Estadual Vale do Acaraú (UVA), Curso de Graduação em Enfermagem. Sobral, Ceará, Brasil. Santa Casa de Misericórdia de Sobral, Serviço de Emergência Adulta. Sobral, Ceará, Brasil.

\section{ABSTRACT}

Objective: To describe the process of construction and validation of an educational booklet for the care of snakebite victims. Methods: Methodological research on the process of building and validating an educational booklet. The construction was developed based on Echer's theoretical framework with validation performed by thirteen judges, from January to April 2019. The items evaluated were the following: structure and appearance; objectives and relevance using the Likert scale. For the validation analysis, the Content Validity Index (CVI) was used, with a cut-off point higher than 0.78.

Results: The booklet contained the following items: Presentation, Snakebite Accidents: What they are, Incidence in Brazil, Santa Casa de Sobral, Types Genus, Signs and Symptoms, Prevention, Immediate Conduct, Severity and Treatment, In-Hospital Care and, finally, References. None of the items evaluated presented a value below the minimum agreement adopted. The global mean of the CVI was 0.94 , confirming the validation of the booklet with the judges. The evaluators also made suggestions, which were accepted. Conclusions: The construction of the material clarified the best care and prevention strategies and its objectives, appearance, structure, and relevance were considered to be in agreement from the validation.

Keywords: Snakebites. Educational technology. Validation study.

\section{RESUMO}

Objetivo: Descrever o processo de construção e validação de uma cartilha educativa para a prestação de cuidados às vítimas de ofidismo

Métodos: Pesquisa metodológica do processo de construção e validação de uma cartilha educativa. A construção foi desenvolvida a partir do referencial teórico de Echer, sendo a validação realizada por treze juízes, de janeiro a abril de 2019. Os itens avaliados foram: estrutura e aparência; objetivos e relevância, utilizando-se da escala tipo Likert. Para a análise da validação, utilizou-se o Índice de Validade de Conteúdo (IVC), com recomendação de ponto de corte superior a 0,78.

Resultados: A cartilha continha os itens Apresentação, Acidentes Ofídicos: 0 que são, Incidência no Brasil, Santa Casa de Sobral, Tipos de Gêneros, Sinais e Sintomas, Prevenção, Condutas Imediatas, Gravidade e Tratamento, Cuidado Intra-hospitalar, e por fim as Referências. Nenhum dos itens avaliados apresentou valor abaixo da concordância mínima adotada. A média global do IVC foi de 0,94, ratificando a validação da cartilha junto aos juízes. Os avaliadores também realizaram sugestões, as quais foram acatadas.

Conclusões: A construção do material clarificou as melhores estratégias de cuidado e prevenção, sendo seus objetivos, sua aparência, estruturação e relevância considerados concordantes a partir da validação.

Palavras-chave: Mordeduras de serpentes. Tecnologia educacional. Estudo de validação.

\section{RESUMEN}

Objetivo: Describir el proceso de construcción y validación de una cartilla educativa para la atención de víctimas de ofidismo. Métodos: Investigación metodológica sobre el proceso de construcción y validación de una cartilla educativa. La construcción se desarrolló en base al marco teórico de Echer, con validación a cargo de trece jueces, entre enero y abril de 2019. Los ítems evaluados fueron los siguientes: estructura y aspecto; objetivos y relevancia, con utilización de la escala Likert. Para el análisis de validación, se utilizó el Î́ndice de Validez del Contenido (IVC), con un punto de corte superior a 0,78.

Resultados: La cartilla contenía los ítems de Presentación, Accidentes por enfermedad: Qué son, Incidencia en Brasil, Santa Casa de Sobral, Tipos de géneros, Signos y síntomas, Prevención, Conducta inmediata, Gravedad y tratamiento, Atención hospitalaria y, finalmente, Referencias. Ninguno de los ítems evaluados presentó un valor por debajo del acuerdo mínimo adoptado. La media global del IVC fue de 0,94, lo que confirma la validación de la cartilla por los jueces. Los evaluadores también hicieron sugerencias, que fueron aceptadas.

Conclusiones: La construcción del material presentó las mejores estrategias de atención y prevención, y sus objetivos, aspecto, estructura y relevancia se consideraron acordes, a partir de la validación.

Palabras clave: Mordeduras de serpientes. Tecnología educativa. Estudio de validación. 


\section{口INTRODUCTION}

Snakebite accidents are a reality very present in the daily life of Brazilians. A number of studies ${ }^{(1-3)}$ have shown the considerable number of people who become victims of venomous snakes, which highlights the relevance of the population's knowledge for prevention strategies, as well as of the professionals, so that they take the appropriate behaviors in the care of such patients.

In Brazil, nearly 390 species of snakes are known, being one of the richest fauna on the planet, where nearly $15 \%$ are considered venomous ${ }^{(4)}$. Brazilian venomous snakes belong to two families: Viperidae (responsible for bothropic, crotalic, and lachesis accidents) and Elapidae (responsible for elapid accidents) ${ }^{(4)}$.

According to data from the Ministry of Health ${ }^{(5)}$, there are nearly 7,000 snakebite accidents a year in the country. Therefore, studies on these types of accidents are important to ensure better conditions for the care and treatment of the victims, in addition to enabling educational measures at all levels of health care ${ }^{(1,6)}$. However, despite the great importance of knowledge about snakebites for public health, aspects related to epidemiological research and to the qualification of the professionals are still little discussed(7).

From this perspective, the relevance of spreading knowledge to the community and health professionals is emphasized. The preparation of educational booklets is thus a viable alternative for information and awareness of such audiences ${ }^{(8)}$. However, in order to maximize the effectiveness of the use of new written materials on health education, it is necessary to know the approach procedures to validate the content, seeking the development of reliable and appropriate instruments for a given population ${ }^{(9)}$.

Therefore, there is the following research question: Does a booklet on care for snakebite victims built on the basis of the professional experience and evidence from the literature prove to be valid according to expert judges?

Given the above, the objective is to describe the process of construction and validation of an educational booklet for the provision of care to victims of snakebite accidents by venomous snakes.

\section{METHODOLOGY}

This is a methodological research study which aims at the development of technological strategies through the systematic use of knowledge that will be implemented, evaluated, and validated in an educational or assistance environment, aiming at the creation of reliable goods and services ${ }^{(9)}$.
The technological strategy of this study is an educational booklet, which followed the construction framework proposed by Echer ${ }^{(10)}$, in the following phases: project design, bibliographic survey, and technology development.

The proposal for the elaboration of a booklet that has important information for the proper management of patients who are snakebite victims emerged from experiences and limitations faced by health professionals in order to properly care for these patients, as well as from dialogs with the health team and with the team of coordinators of an emergency service of a teaching hospital in the North Zone of the state of Ceará, where the study was conducted.

The bibliographic survey was based on the analysis of data referring to the clinical and epidemiological profile of the patients treated at the aforementioned hospital, as well as of diverse information provided by the reference literature of the Ministry of Health in the Handbook of Diagnosis and Treatment of Accidents by Venomous Animals ${ }^{(5)}$ and in the Health Surveillance Guide ${ }^{(11)}$. The $75^{\text {th }}$ volume of the Veterinary and Zootechny Technical Notebooks was also used (12).

The initial version of the booklet was prepared between April and July 2018 and was entitled "Snakebite accidents by venomous snakes: characteristics of species, signs and symptoms, diagnosis, and treatment", with the final version being organized in sixteen pages. Then, it went through a process of evaluation by specialists for validation, from January to April 2019.

Validation analysis was performed using the Content Validity Index $(\mathrm{CVI})$, which measures the proportion of agreement on a certain aspect of an instrument and its items ${ }^{(13)}$. Each item was analyzed separately using the Likert-type scale, organized in scores from 1 to 4, where: 1) inadequate; 2) partially adequate; 3 ) adequate; and 4) totally adequate. Alternatives 3 and 4 were considered to be in agreement.

The choice of the evaluators was performed in order to contemplate the physicians and nurses of the service where the study was developed. The inclusion criteria were being a physician or a nurse in the hospital service in question and having more than one year of service in the emergency department, excluding those who refused to participate in the analysis of the material. Thus, thirteen judges evaluated the booklet and, in this case, the literature recommends an agreement rate of not less than $0.78^{(13)}$, according to the $\mathrm{CVI}$, while for the complete evaluation of the booklet, the sum of all the CVIs was calculated separately, dividing them by the number of items in the instrument.

All the evaluators received the first version of the printed booklet, as well as the evaluation instrument and the Free and Informed Consent Form. They were instructed to return the materials within a maximum period of fifteen days. 
Subsequently, the data collected through the evaluation instrument was organized in a Microsoft Excel 2013 spreadsheet, and was organized in tables for further discussion in the light of the updated scientific literature.

The appraisal with a favorable opinion of the Ethics Committee in Research with Human Beings of the State University of Vale do Acaraú under number 2,578,006 and CAAE 85033318.8.0000.5053 on 04/03/2018 is highlighted.

\section{RESULTS}

The booklet entitled "Snakebite accidents by venomous snakes: characteristics of species, signs and symptoms, diagnosis, and treatment" is organized in an external and internal part. The external part has the cover, while the inside is grouped into pre-textual, textual, and post-textual elements. The pre-textual element concerns the topic of "Presentation", the textual elements concern the content itself, which has the topics of "Snakebites Accidents: What are they?", "Incidence in Brazil," "Santa Casa de Misericórdia de Sobral", "Types of Genus", "Signs and Symptoms,",Prevention", "Immediate Conduct", "Severity and Treatment" and "In-hospital Care" and, finally, the "References" are at the end of the booklet as post-textual element.

Its validation was carried out regarding the achievement of objectives, structure, appearance, and relevance. The validation was developed by two physicians and eleven nurses. The mean age of the participants was 32 years old, while the mean working time of these professionals in the emergency service was 4.5 years, ranging from two to eight years. Regarding their degrees, $8 \%$ (1) have a master's degree and $92 \%$ (12) have a specialization in urgencies and emergencies.

The validation of the educational technology occurred through the calculation of the CVI (Table I), in which the $n$ value represents the total of evaluators who considered the variable in agreement, marking it as totally adequate or adequate, with CVIs greater than 0.78 being accepted.

Table 1 - Content Validity Index for each element of the educational technology. Sobral, 2019

Items of the Educational Booklet

\section{Objectives}

They are consistent with the needs of the service professionals and of the population's knowledge

It promotes guidance in relation to patient management

It can help the performance of the health professional

$13 \quad 1.0$

\section{Structure and Appearance}

The information is presented clearly and objectively

The presented information is scientifically correct

$13 \quad 1.0$

The material is adequate for understanding

There is a logical sequence of the exposed content

The font size of the title and texts is adequate

The illustrations are adequate for understanding and in sufficient numbers

The material (paper, printing, and colors) is appropriate

$12 \quad 0.92$

\section{Relevance}

The theme is a subject that must be reinforced

The booklet guides the provision of better patient care

The booklet is an instrument that hinders the occurrence of mistakes

It is adequate for use by any service professional and for preventing cases with the population

$12 \quad 0.92$

Source: The authors, 2019 
In most of the items evaluated, a CVI of at least 0.84 was found. None of the values was below the minimum agreement adopted. Therefore, it was not necessary to make changes at this stage of the validation. The general CVI mean for objectives and relevance was 0.92, while for structure and appearance it was 0.98. The global mean was 0.94, confirming the validation of the booklet with the judges.

Complementary to this, the judges'suggestions regarding the structure and appearance of the material were also analyzed, as described in Chart 1.

\begin{tabular}{|l|l|}
\hline $\begin{array}{l}\text { Suggestions } \\
\begin{array}{l}\text { Insert specific } \\
\text { in-hospital care } \\
\text { for each species }\end{array}\end{array}$ & $\begin{array}{l}\text { The in-hospital care for each } \\
\text { species was inserted in the topic } \\
\text { of "In-hospital Care" }\end{array}$ \\
\hline $\begin{array}{l}\text { Language } \\
\text { simplification }\end{array}$ & $\begin{array}{l}\text { The meaning of all the technical } \\
\text { terms was inserted after their } \\
\text { descriptions, in parentheses }\end{array}$ \\
\hline $\begin{array}{l}\text { Include an alert } \\
\text { about the need } \\
\text { for notification }\end{array}$ & $\begin{array}{l}\text { A red tag was inserted in the topic } \\
\text { of "Severity and Treatment", with } \\
\text { the following phrase: "Attention, } \\
\text { health professionals: Accidents } \\
\text { with venomous animals must be } \\
\text { notified in the SINAN" }\end{array}$ \\
\hline
\end{tabular}

Chart 1 - Judges'suggestions for the structure and appearance of the educational technology. Sobral, 2019 Source: The authors, 2019.

The educational material validated by the judges culminated in the definitive characteristics described below. The cover of the booklet is black, with the title highlighted on the top and the full name of the authors on the bottom. In the central region, an image of a snake of the Bothrops genus, popularly known as jararaca was used, since it is the snake that causes the largest number of accidents in the region, annually.

On page 2 there is the presentation of the booklet, which clarifies the content covered in the material, as well as the reason that led to the idealization of the technology. In its initial textual element, defined as "Snakebites Accidents: What are they?", there is a definition and explanation about the subject matter addressed, having as reference the Health Surveillance Guide, published in 2017 by the Ministry of Health ${ }^{(11)}$. In the second topic, called "Incidence in Brazil", there is an explanation about the epidemiology of snakebites caused by venomous snakes, whose information is brought in the Handbook of Diagnosis and Treatment of Accidents by Venomous Animals, also published by the Ministry of Health in $2001^{(5)}$.

The topic of "Santa Casa de Misericórdia de Sobral" presents the clinical and epidemiological profile of the patients who were treated at this institution in the years 2017 and 2018. The data presented for the purpose of general knowledge will serve to demonstrate that the prevalence of such accidents is significant, which reinforces the importance of the technology and draws the interest of the reader in the material, since it is a common local reality.

In the topic of "Types of genus", information about the main characteristics of the snakes that victimize people in the region is exposed, using images in order to increase the chances of recognizing the snake involved in the accident. Soon after, in "Signs and Symptoms", the main clinical manifestations of the snakebite accidents mentioned are described, as well as images of the signs described in text. The objective is to convey, both to the professionals and to the population, the specific signs and symptoms of each type of accident.

The document continues with the topic of "Prevention", which presents the main ways to prevent the occurrence of accidents. In "Immediate conduct", the attitudes that must be taken are presented, as well as those that must be avoided for a possible negative evolution of the case.

Subsequently, the topic of "Severity and Treatment" is explained, where there is a table with the classification of the severity of the types of accidents and the number of ampoules that must be administered according to severity and an alert for the notification of cases. The last textual topic, "In-hospital Care", describes the necessary care in the hospital setting, as well as the necessary conducts and the medications that can be prescribed. At the end, the references used to construct the instrument are presented.

The booklet described is available in its entirety free of charge in the following link: https://drive.google. com/file/d/10Y3mYHa-8mhyYWXQYujh8IEIVwVxLz1E/ view?usp=sharing

\section{DISCUSSION}

The educational booklet under study was validated by judges based on the CVI, reaching satisfactory indexes in all the variables evaluated: objectives, appearance, structure, and relevance. Despite the global CVI having a value of 0.94, the judges still elucidated changes to improve the material, which were met.

Other studies ${ }^{(8,14-15)}$ that validated booklets also used the $\mathrm{CVI}$ to validate the material and needed to undergo 
adjustments until the final version was reached, which demonstrates the relevance of carrying out this stage for the development of a qualified educational technology.

Therefore, the elaboration of the booklet entitled "Snakebite accidents by venomous snakes: characteristics of species, signs and symptoms, diagnosis, and treatment"and its validation aim to favor the improvement of the quality of assistance provided to the user who is victim of a snakebite accident, and its use as a guide for orientations will result in more confident professionals conducting such patients. Thus, the importance is reasserted of educational technologies in the care process on themes that need more research studies and reflections ${ }^{(8,15)}$.

In this sense, it is understood that, if the patient is assisted in a short period of time and a correct diagnosis is made with a trained professional, the chance is high of not having sequels from the attacks of these animals ${ }^{(3)}$. Therefore, knowledge about this theme is essential for all the professionals.

On the other hand, the same technology is characterized as an effective strategy for health promotion while improving the patients' knowledge and coping, making them able to understand the prevention strategies arising from actions performed individually ${ }^{(16)}$.

This way, aspects such as language, the use of images, and the organization of the booklet, must be adequate for all the intended audiences. In the context under discussion, the judges requested the definition of all the technical terms used in the booklet. Therefore, a printed material may direct, standardize, and stimulate health education actions and guidelines with illustrations, and with a clear and understandable language for all levels of society ${ }^{(17)}$. Thus, the technical language was adopted in the booklet with its respective definition in parentheses, which favors the understanding of both the population and the professionals.

It was also chosen to use images that exemplify the theoretical descriptions, making the content didactic and attractive. Thus, once understandable and attractive, the educational materials are characterized as an alternative to raise patient awareness so that they can be active in their care process ${ }^{(18)}$. However, although the acquisition of new knowledge is not enough to produce a change in behavior in relation to the problem situation, in society in general it is noticed that, on several occasions, technical knowledge is missing and that, when this knowledge is shared with people in a concrete and well-argued way, it can produce behavioral changes ${ }^{(19)}$.

In this perspective, the contributions of this study to the spread of knowledge about the prevention and treatment of snakebites are highlighted, in view of the scarcity of updated documents on the subject matter in the scientific literature, even of the reference productions of the Ministry of Health ${ }^{(5,11)}$.

The present study had as a limitation its non-validation with the general population, which makes it impossible to understand the level of understanding of this audience. However, its use as a health education instrument is indispensable, as it will assist the professionals in carrying out dialogs with the population during the teaching and learning process.

It is also believed that it is pertinent to verify the effectiveness of educational material in patient orientation. This can be done individually or collectively with the target audience ${ }^{(18)}$.

\section{CONCLUSION}

The educational booklet was built from the bibliographic survey in the reference literature of the subject matter (guides and handbooks from the Ministry of Health). The validation by judges obtained a global CVI of 0.94 , taking into account the achievement of its objectives and aspects related to appearance, structure, and relevance, which confirms its use. Thus, the material is configured as an education strategy for the general population, considering that it has diverse information regarding prevention and immediate care after the snakebite, and is also an orientation for the professional that will facilitate the care process.

The construction and validation of the booklet as an instrument of nursing care revealed itself as a potential for health education and as a scientific attribute of the professional performance. In addition, it is reinforced that it is an accessible and low-cost didactic material for the transmission of knowledge, and its use is possible in different health contexts.

It is hoped that this study encourages the construction of new teaching tools for the discussion about snakebites and that the booklet, available in a link in the manuscript, may be used in different regions of the country by professionals from different health areas. Further research studies are also suggested to enable the population to evaluate the material.

\section{Q REFERENCES}

1. Lopes AB, Oliveira AA, Dias FCF, Santana VMX, Oliveira VS. Perfil epidemiológico dos acidentes por animais peçonhentos na região Norte entre os anos entre 2012 e 2015: uma revisão. Rev Patol Tocantins. 2017 [cited 2019 Jul 15];4(2). Available from: https://sistemas.uft.edu.br/periodicos/index.php/patologia/ article/view/3753 
2. Machado C, Lemos ERS. Ofidismo no Estado do Rio de Janeiro, Brasil, no período de 2007-2013. Rev Eletr Estácio Saúde. 2016 [cited 2019 Jul 15];5(2):67-77. Available from: http://revistaadmmade.estacio.br/index.php/ saudesantacatarina/article/viewFile/2510/1314

3. Ximenes LMAS, Santana LS, Silva OMC, Santana MS. Perfil dos acidentes ofídicos ocorridos no município de Alta Floresta - Mato Grosso. Encicl Biosfera. 2018;15(7):1458-74. doi: https://doi.org/10.18677/EnciBio_2018A125

4. Costa HC, Bernils RS. Répteis brasileiros: lista de espécies 2015. Herpetol Bras. 2015 [cited 2019 Jul 15];4(3):75-80. Available from: https://www. researchgate.net/profile/Henrique_Costa5/publication/289504875_Repteis_ brasileiros_Lista_de_especies_2015/links/568d464f08ae78cc0514150a/ Repteis-brasileiros-Lista-de-especies-2015.pdf

5. Ministério da Saúde (BR). Fundação Nacional de Saúde. Manual de diagnóstico e tratamento de acidentes por animais peçonhentos. 2a ed. Brasília: Fundação Nacional de Saúde; 2001 [cited 2019 Jul 15]. Available from: https://www. icict.fiocruz.br/sites/www.icict.fiocruz.br/files/Manual-de-Diagnostico-eTratamento-de-Acidentes-por-Animais-Pe--onhentos.pdf

6. Cunha VP, Santos RVSG, Ribeiro EEA, Maia Filho ALM, Marques RB. Perfil epidemiológico de acidentes com animais peçonhentos no Piauí. Revinter. 2019;12(1):76-87. doi: https://doi.org/10.22280/revintervol12ed1.399

7. Schier DT, Lemos MR, Campos CGC, Cardoso JT. Estudo sobre a influência de variáveis metereológicas nos casos de acidentes por animais peçonhentos em Lages - SC. Hygeia. 2019;15(31):43-55. doi: https://doi.org/10.14393/ Hygeia153146311

8. Benevides JL, Coutinho JFV, Pascoal LC, Joventino ES, Martins MC, Gubert FA, et al. Development and validation of educational technology for venous ulcer care. Rev Esc Enferm USP. 2016;50(2):309-16. doi: https://doi.org/10.1590/ S0080-623420160000200018

9. Polit DF, Beck CT. Fundamentos da pesquisa em enfermagem: avaliação de evidências para a prática de enfermagem. 9a ed. Porto Alegre: Artmed; 2018.

10. Echer IC. Elaboração de manuais de orientação para 0 cuidado em saúde. Rev Latino-Am Enfermagem. 2005;13(5):754-7. doi: https://doi.org/10.1590/ S0104-11692005000500022

\section{- Conflicts of Interest:}

There are no conflicts of interest to declare.

\section{- Contributions:}

All the authors contributed in data collection and analysis, as well as in the elaboration and review of this article.

\section{- Funding Source:}

Santa Casa de Misericórdia de Sobral (SCMS).

\section{- Funding Body:}

Teaching, Research and Extension Department (Departamento de Ensino, Pesquisa e Extensão, DEPE) of Santa Casa de Misericórdia de Sobral (SCMS).
11. Ministério da Saúde (BR). Secretaria de Vigilância em Saúde. CoordenaçãoGeral de Desenvolvimento da Epidemiologia em Serviços. Guia de Vigilância em Saúde: volume único. 2. ed. Brasília: Ministério da Saúde; 2017 [cited 2019 Jul 20]. Available from: http://portalarquivos.saude.gov.br/images/pdf/2017/ outubro/06/Volume-Unico-2017.pdf

12. Animais peçonhentos. Cad Téc Vet Zoot. 2014 dez [cited 2019 Jul 10];(75). Available from: https://vet.ufmg.br/ARQUIVOS/FCK/file/editora/caderno\%20 tecnic0\%2075\%20animais\%20peconhentos.pdf

13. Costa ANM, Orpinelli CMZ. Validade de conteúdo nos processos de construção e adaptação de instrumentos de medidas. Ciênc Saúde Coletiva. 2011;16(7):30618. doi: https://doi.org/10.1590/S1413-81232011000800006

14. Lima ACMACC, Bezerra KC, Sousa, DMN, Rocha JF, Oriá MOB. Development and validation of a booklet for prevention of vertical HIV transmission. Acta Paul Enferm. 2017;30(2):181-9. doi: https://doi.org/ 10.1590/1982-0194201700028

15. Gonçalves MS, Celedônio RF, Targino MB, Albuquerque TO, Flauzino PA, Bezerra AN, et al. Development and validation of an educational booklet for health eating promotion among diabetic patients. Rev Bras Promoç Saúde. 2019;32:7781. doi: https://doi.org/10.5020/18061230.2019.7781

16. Silveira MS, Cogo ALP. The contributions of digital technologies in the teaching of nursing skills: an integrative review. Rev Gaúcha Enferm. 2017;38(2):e66204. doi: https://doi.org/10.1590/1983-1447.2017.02.66204

17. Albuquerque AFLL, Pinheiro AKB, Linhares FMP, Guedes TG. Technology for selfcare for ostomized women's sexual and reproductive health. Rev Bras Enferm. 2016;69(6):1164-71. doi: https://doi.org/10.1590/0034-7167-2016-0302

18. Moreira XMA, Fontenele NAO, Bastos IB, Macêdo TS, Galindo Neto NM, Caetano $J A ́$, et al. Construction and validation of educational booklet content for fall prevention in hospitals. Acta Paul Enferm. 2019;32(4):433-41. doi: https://doi. org/10.1590/1982-0194201900059

19. Wild CF, Nietsche EA, Salbego C, Teixeira E, Favero NB. Validation of educational booklet: an educational technology in dengue prevention. Rev Bras Enferm. 2019;72(5):1318-25. doi: https://doi.org/10.1590/0034-7167-2018-0771

\section{- Corresponding author:}

Kairo Cardoso da Frota

E-mail: kairo.enfer@gmail.com

Associate editor:

Carlise Rigon Dalla Nora

Approved: 02.12.2020

\section{Editor-in-chief:}

Maria da Graça Oliveira Crossetti 